\title{
Nursing care for the person with gastrostomy: integrative review
}

\section{Cuidado de enfermagem à pessoa com gastrostomia: revisão integrativa}

\section{Cuidados de enfermería a la persona con gastrostomía: revisión integral}

\author{
Thays Paula da Silva ${ }^{1}$, Carla Rodrigues Gama Ribeiro², Zélia Marilda Rodrigues Resck ${ }^{1,2}$, \\ Silvana Maria Coelho Leite Fava1,2, Eliza Maria Rezende Dázio1,2
}

\section{ORCID IDs}

Silva TP (iD https://orcid.org/0000-0002-5760-5348

Ribeiro CRG (D) https://orcid.org/0000-0001-5037-1510

Resck ZMR (D) https://orcid.org/00000002-3752-8381

Fava SMCL (iD https://orcid.org/0000-0003-3186-9596

Dázio EMR iD https://orcid.org/0000-0001-9216-6283

\section{HOW TO CITE}

Silva TP; Ribeiro CRG; Resck ZMR; Fava SMCL; Dázio EMR. Nursing care for the person with gastrostomy: integrative review. ESTIMA, Braz. J. Enterostomal Ther., 16: e0718. doi: 10.30886/estima.v16.374.

\begin{abstract}
Objective: To analyze the national and international scientific productions developed by nurses about the care of the person with gastrostomy. Method: Integrative review including articles published by nursing, from 2005 to 2015, in national and international journals and that answer the following guiding question: What has been produced by nursing about the care of the person with gastrostomy? Articles in Portuguese, Spanish and English, available totality, were established as inclusion criteria. The databases used were: PUBMED, Nursing Database (BDENF), Scopus and Web of Science. The Boolean operators AND/OR were used as well as the descriptors selected in the Descriptors in Health Sciences: "gastrostomy" AND "family nursing", from the integrated method in Portuguese and English. Results: Eight articles answered the guiding question. It was verified that in the multidisciplinary team the role of the nurse is fundamental, both in the hospital and at home, to guarantee the care of the child, the adult and the elderly with gastrostomy. Conclusion: In planning care, nurses should have technical and scientific knowledge, better explore their clinical role and understand the needs of the person with gastrostomy and it family. The studies highlighted the scarcity of scientific productions about the theme.
\end{abstract}

DESCRIPTORS: Gastrostomy; Family nursing; Stomatherapy

${ }^{1}$ Universidade Federal de Alfenas - Escola de Enfermagem - Curso de Graduação em Enfermagem - Alfenas/MG - Brazil.

2Universidade Federal de Alfenas - Escola de Enfermagem - Programa de Pós-Graduação em Enfermagem - Alfenas/MG - Brazil. Correspondence author: Eliza Maria Rezende Dázio | Rua Gabriel Monteiro da Silva, 700 - Centro | ZIP Code: $37130-000$ - Alfenas/MG Brazil | E-mail: elizadazio@yahoo.com.br

Received: June 232016 | Accepted: June 062017 


\section{RESUMO}

Objetivo: Analisar as produções científicas nacionais e internacionais desenvolvidas por enfermeiros acerca do cuidado à pessoa com gastrostomia. Método: Revisão integrativa incluindo artigos publicados pela enfermagem, no período de 2005 a 2015, em periódicos nacionais e internacionais e que respondessem à seguinte questão norteadora: O que tem sido produzido pela enfermagem acerca do cuidado à pessoa com gastrostomia? Estabeleceram-se como critérios de inclusão artigos em Português, Espanhol e Inglês, disponíveis na íntegra. As bases de dados utilizadas foram: PUBMED, Base de Dados em Enfermagem (BDENF), Scopus e Web of Science. Os operadores booleanos AND/OR foram utilizados, bem como os descritores selecionados no Descritores em Ciências da Saúde: "gastrostomia" OR "gastrostomy" AND "enfermagem da família" OR "family nursing", a partir do método integrado, em Português e Inglês. Resultados: Oito artigos responderam à questão norteadora. Verificou-se que na equipe multiprofissional o papel do enfermeiro é fundamental, tanto no hospital quanto no domicílio, para garantia do cuidado à criança, ao adulto e ao idoso com gastrostomia. Conclusão: No planejamento da assistência, o enfermeiro deve ter conhecimento técnico e científico, explorar melhor o seu papel clínico e apreender as necessidades da pessoa com gastrostomia e da sua família. Os estudos destacaram a escassez de produções científicas sob a temática.

DESCRITORES: Gastrostomia; Enfermagem da família; Estomaterapia

\section{RESUMEN}

Objetivo: Analizar las producciones científicas nacionales e internacionales desarrolladas por enfermeros acerca del cuidado a la persona con gastrostomía. Método: Revisión integral incluyendo artículos publicados por enfermería, en el período del 2005 al 2015 , en periódicos nacionales e internacionales y que responden a la siguiente cuestión orientadora: ¿Qué ha sido producido por enfermería acerca del cuidado a la persona con gastrostomía? Se establecieron criterios de inclusión, artículos en portugués, español e inglés, disponibles integralmente. Las bases de datos usadas fueron: PUBMED, Base de Datos en Enfermería (BDENF), Scopus y Web of Science. Los conectores lógicos AND/OR fueron usados, como también los descriptores seleccionados en Descriptores en Ciencias de la Salud: "gastrostomía" OR "gastrostomy" AND "enfermería de la familia" OR "family nursing", a partir del método integrado, en portugués e inglés. Resultados: Ocho artículos respondieron a la cuestión orientadora. Se verificó que en el equipo multiprofesional el papel del enfermero es fundamental, tanto en el hospital como en el domicilio, para garantía del cuidado a los niños, al adulto y al anciano con gastrostomía. Conclusión: En la planificación de la asistencia, el enfermero debe tener conocimiento técnico y científico, explorar mejor su papel clínico y aprender las necesidades de la persona con gastrostomía y de su familia. Los estudios destacaron la escasez de producciones científicas bajo esta temática.

DESCRIPTORES: Gastrostomía; Enfermería de la familia; Estomatoterapia

\section{INTRODUCTION}

Ostomy or stoma are terms of Greek origin that indicate the exteriorization of a hollow viscera, by means of a surgical procedure, to allow the administration of diets and the drainage of secretions, feces or urine. It receives the denomination according to the organ in which it was constructed, thus, if in the stomach, one has a gastrostomy ${ }^{1,2}$.

It is a surgical procedure in which an opening is made in the stomach for the introduction of a probe, in order to guarantee food support for those who use longterm nasal or oral probes or for gastric decompression ${ }^{3}$.

The care for people with gastrostomy in public health systems occurs at the time of disease exacerbation and often in a fragmented way, since the emphasis on the technical-procedural. The gastrostomy implies a change in the body image, the identity and the way of feeding, since from the accomplishment of this procedure there are changes in the diet and the route of administration, passing through a probe inserted directly into the stomach ${ }^{4}$.

In this sense, the multidisciplinary health team must commit to the care of these people, especially the nurse, who must plan the care with a view to the care of the human being in its various dimensions. Thus, it is important to understand that in the face of the process of illness that culminates in a gastrostomy, the person may not accept its actual state of health and need time to reformulate concepts for the "sizing of losses and to find forces to reorganize the life "4.

In this context, based on the premise that the nurse should plan the care of people with a gastrostomy considering their biopsychosocial and spiritual dimensions, it is essential to exhibit what nursing has produced about the care of the person with gastrostomy. 


\section{OBJECTIVE}

To analyze the national and international scientific productions developed by nurses about the care of the person with gastrostomy.

\section{METHODS}

It is an integrative review ${ }^{5}$ of the literature realized in six stages.

In the first stage, the definition of the topic of the study and the formulation of the objective and the guiding question of the study were realized, specifically: "What has been published by the nursing about the care of the person with gastrostomy?".

In the second stage, the criteria for inclusion of studies to guide search and selection were established, being: articles in Portuguese, Spanish and English, available totality in the databases and published in the period from 2005 to 2015. The books, conference reports, conference abstracts, theses and dissertations, epidemiological data and those that presented duplication in the databases were excluded. The databases used were: PubMed, Nursing Database (BDENF), Scopus and Web of Science. The Boolean operators AND/OR were used and the descriptors extracted from the Descriptors in Health Sciences - Bireme (DiHS) in Portuguese and English: "gastrostoma" OR "gastrostomy" AND "family nursing" OR "familynursing", from integrated method.

In the third stage, the information to be extracted from the selected studies was defined: title of the article, authors, year, country of publication, objectives and conclusions. This information was cataloged in a table by the researchers, using the program Microsoft Word.

In the fourth stage, the thematic analysis of included studies was realized observing similarities and differences between them. In the fifth, the interpretation of the results was developed and the nursing care was evaluated to the person with gastrostomy, which enabled the identification of knowledge gaps. Finally, in the sixth and last stage, a synthesis of the knowledge and the main results evidenced on the analysis of the included studies was made, which allowed the construction of the following theme: The care of the patient with gastrostomy in the pre- and postoperative period.

\section{RESULTS}

It were found 12 articles in the selected databases. Of these, only eight had the established inclusion criteria. Among the articles selected, five are from international journals, two of which were developed in Spain, two in the United States of America and one in the United Kingdom; the remaining three, in Brazil. The articles were published in the period from 2007 to 2015 .

Table 1 shows the distribution of publications according to title, authors, objective, conclusion and level of evidence ${ }^{6}$. The following classification of levels of evidence was adopted: Level I - Systematic reviews or meta-analysis of Clinical Study with randomization, level II - Clinical Study with randomization, level III - Clinical Study without randomization, level IV Cohort and Case control, level V - Systematic review of descriptive/qualitative studies, level VI - Descriptive/ qualitative studies and level VII - Opinion ${ }^{6}$.

The texts presented nursing care with emphasis on procedural technical nursing, followed by patient/ family relational care.

\section{DISCUSSION}

At present, the number of patients in hospitals and in the community who have a gastrostomy, especially percutaneous endoscopic (PEG), is significant.

This technique has been expanding in recent years due to its safety, its low cost and the fact that it offers the best way for the nutrition of patients with dysphagia or unable to eat orally, even with a functioning digestive tract $^{8,9}$.

As members of the multidisciplinary team, nurses are primarily responsible for patient care submitted for this procedure ${ }^{10}$. For this purpose, they must be prepared to provide qualified assistance to it, as well as support and guidance to its family ${ }^{11}$. The analysis of the scientific production on the subject indicates that the nursing care of the person with gastrostomy is still incipient, which conforms to the authors ${ }^{12}$.

In the preoperative period, interventions should be included in nursing care planning to ensure better confront of the new condition and patient guidance 
Table 1. Distribution of publications according to title, authors, objective, conclusion, year of publication and level of evidence. Alfenas, Minas Gerais, Brazil, 2016.

\section{Title}

Authors
Objectives
Level of evidence

$\begin{array}{ll}\text { Percutaneous } & \text { Friginal- } \\ \text { endoscopic } & \text { Ruiz AB, } \\ \text { gastrostomy: } & \text { González- } \\ \text { an update on } & \text { Castillo S e } \\ \text { indications, } & \text { Lucendo AJ } \\ \text { technique and } & (2011)^{6} \\ \text { nurse care } & \end{array}$

Home

percutaneous

endoscopic

gastrostomy

feeding:

perceptions of

patients, carers,

nurses and

dietitians
To present

indications,

contraindications,

advantages and

disadvantages

of percutaneous

endoscopic

gastrostomy (PEG).

Feeding through the PEG probe is a procedure used to nourish patients with dysphagia or unable to feed themselves orally, even with a functioning digestive tract. The technique has been expanding in recent years because of its safety and its low cost. For its correct realization, it is necessary to have degree and training of the responsible professionals of this procedure, whose function also extends to the training and information of other professionals and caregivers involved in patient care. The administration of appropriate, adapted and personalized care minimizes the risk of complications.

To compare the perceptions of adult patients, family caregivers, nurses and nutritionists about percutaneous endoscopic gastrostomy feeding at home.
There is a necessity for greater involvement of the patient and the caregiver in the decision-making process and for sufficient, adequate information to facilitate decision-making. Professionals who involve caregivers in decision making, in situations where patients are unable to do so, need to be aware that caregivers may not represent patients' opinions.
Percutaneous endoscopic gastrostomy: an update on its indications, management, complications, and care
To analyze the effects of gastric probing in patients with cerebrovascular accident and dysphagia.
PEG feeding is the most valuable way of access for nutrition in patients with a functional gastrointestinal system. Its high efficiency, safety and low cost are based on its growing popularity worldwide.
The

percutaneous endoscopic gastrostomy tube: a nurse's guide to PEG tubes Friginal-Ruiz AB (2014)

\section{The literature is inconsistent in} recommendations for the care of the patient receiving PEG feeding. To give these patients the best care possible, nurses and prospective nurses need will allow safe enteral nutrition for the patient receiving long-term nutritional support.

$\begin{array}{lll}\begin{array}{l}\text { O cuidado } \\ \text { à pessoa }\end{array} & \text { Souza JL, } & \begin{array}{l}\text { To know the role } \\ \text { of the familiar }\end{array} \\ \text { portadora de } & \text { Gomes GC, } & \text { caregiver with the } \\ \text { estomia: o papel } & \text { Barros EJLB } & \text { person with the } \\ \text { do familiar } & (2009)^{13} & \begin{array}{l}\text { stoma in their } \\ \text { adaptive period. }\end{array} \\ \text { cuidador } & & \text { ada }\end{array}$

It is concluded that the family will be more able to care if it is also cared for and potentiated for care. current nursing textbooks and manuals of procedures that reflect the bestknown evidence. Nursing care reported

$\begin{array}{ll}\text { Simons S e } & \begin{array}{l}\text { information in the } \\ \text { form of a guide }\end{array} \\ \text { Remington } & \text { on the handling } \\ \text { R }(2013)^{8} & \begin{array}{l}\text { of PEG tubes for } \\ \text { nurses. }\end{array}\end{array}$

Simons S e Remington (a) of PEG tubes for nurses.

Provide information in the form of a guide (1) 
Table 1. Continuation...

\begin{tabular}{|c|c|c|c|c|}
\hline Title & Authors & Objectives & Conclusion & $\begin{array}{l}\text { Level of } \\
\text { evidence }\end{array}$ \\
\hline $\begin{array}{l}\text { PEG tubes: } \\
\text { dealing with } \\
\text { complications }\end{array}$ & $\begin{array}{l}\text { Malhi H, } \\
\text { Thompson R } \\
(2015)^{16}\end{array}$ & $\begin{array}{l}\text { Provide nurses } \\
\text { with information } \\
\text { on how to deal with } \\
\text { complications that } \\
\text { may arise with PEG. }\end{array}$ & $\begin{array}{l}\text { Many patients in hospitals and in the } \\
\text { community, have PEG. Nurses in care } \\
\text { of these patients need knowledge and } \\
\text { skills to ensure proper care, otherwise } \\
\text { a detrimental effect may occur on } \\
\text { nutrition and drug administration } \\
\text { and difficulty to confrontation with } \\
\text { the new condition on the part of the } \\
\text { patient. }\end{array}$ & VI \\
\hline $\begin{array}{l}\text { Assistência de } \\
\text { enfermagem a } \\
\text { pacientes gas- } \\
\text { trostomizados } \\
\text { baseada em } \\
\text { evidências }\end{array}$ & $\begin{array}{l}\text { Nascimento } \\
\text { NG, Borges } \\
\text { EL, Donoso } \\
\text { MTV }(2015)^{10}\end{array}$ & $\begin{array}{l}\text { Establish nursing } \\
\text { recommendations } \\
\text { for implantation, } \\
\text { handling and } \\
\text { withdrawal of } \\
\text { the gastrostomy } \\
\text { probe and to } \\
\text { classify levels } \\
\text { of evidence of } \\
\text { recommendations. }\end{array}$ & $\begin{array}{l}\text { Even though it is a relevant topic, there } \\
\text { is a gap in the literature on nursing care } \\
\text { for gastrostomized patients. }\end{array}$ & $\mathrm{VI}$ \\
\hline $\begin{array}{l}\text { A visão da } \\
\text { família sobre a } \\
\text { experiência de } \\
\text { ter uma criança } \\
\text { gastrostomi- } \\
\text { zada }\end{array}$ & $\begin{array}{l}\text { Cruz AC, } \\
\text { Angelo M, } \\
\text { Gamboa } \\
\text { SNG }(2012)^{15}\end{array}$ & $\begin{array}{l}\text { Identify the } \\
\text { scientific evidence } \\
\text { about the family } \\
\text { experience of a } \\
\text { gastrostomized } \\
\text { child. }\end{array}$ & $\begin{array}{l}\text { The family needs to receive information } \\
\text { and support from the health team that } \\
\text { accompanies the child. }\end{array}$ & $\mathrm{VI}$ \\
\hline
\end{tabular}

before and after the procedure on the changes that will occur in body image and in the form of food, as well as to prepare it, together with the relative, for the return to the home ${ }^{10,13}$.

Even at this stage, it is important that a physical examination of the abdomen is performed to demarcate the best place to perform the procedure. It is recommended that the gastrostomy be performed in places far from ribs, skin folds and bony prominences, so that lesions or leaks from compression do not occur ${ }^{14}$.

It are also important: informed consent; the gauging of vital signs; the previous fast of six hours or according to the institutional protocol; the suspension of platelet antiaggregant, anticoagulants and anti-inflammatories; venipuncture and administration of prescribed fluids; hygiene of the abdominal skin of the oropharyngeal cavity; administration of broad-spectrum antibiotics 30 minutes before to the procedure, in accordance with the institutional protocol; and, if necessary, the removal of dental prostheses and aspiration of secretions ${ }^{4}$.
In the postoperative period, the nursing team should pay special attention to the presence of bleeding and pain complaints, fixation of the probe and fasting for at least four hours in the adult; according to the institutional protocol, water administration should be initiated and, after evaluation, a diet with smaller volumes to reach the ideal amount ${ }^{8}$.

About the drug administration care, like pill, these should be crushed and diluted to avoid probe obstruction. $50 \mathrm{~mL}$ of water should be administered before and after the drug.

However, drug administration, as well as feeding, should be discontinued in the presence of complications. At hospital discharge, the patient should be advised to look for the emergency service immediately if it perceives complications ${ }^{7}$.

It should be emphasized that during the entire hospitalization period and at discharge the skin around the gastrostomy should receive special attention in relation to the presence of phlogistic signs, often resulting from leak of gastric contents ${ }^{8}$. 
In addition, in case of accidental withdrawal of the probe, the patient and/or family member should be advised to position it temporarily and to look for medical assistance immediately for its replacement, within 24 hours after the procedure has been performed recently, the stoma may close within a few hours. In these cases, the Foley probe should be placed provisionally until replacement is performed ${ }^{8,10}$.

The person undergoing gastrostomy should be prepared for self-care, with a view to empowerment and independence. Thus, throughout the hospitalization period, the nursing team should involve it, whenever possible, in all the care provided. It is important to demonstrate how to check the gastric residuals before the administration of the diet, with the aid of a syringe, and how to proceed with the hygiene of the externalized probe, which according to literature recommendations should be made with soap and water clockwise and counterclockwise. Signs of compression of the probe on the skin should be observed and the use of moisturizing creams in the skin should not be used around the gastrostomy ${ }^{15}$.

It is understood that the person with gastrostomy should receive care from a multidisciplinary health team. In this context, nurses play a very important role in planning care for the person and his family. Therefore, it is necessary to know the life context, the knowledge and the practices of these people for the coexistence with the gastrostomy, which contributes to minimize the impact of the chronic illness. Assessment of the patient's remaining capacities and available resources corroborates adequate self-care, improved quality of life, and return to activities ${ }^{15}$.

Nursing professionals should also consider that the patient submitted to gastrostomy pass by a body image alteration, which can generate, especially after the procedure, a feeling of outrage ${ }^{14}$. From the Nursing Process it is possible to identify the needs of the person with gastrostomy and it family ${ }^{15}$ and implement with the multidisciplinary team the resources to attend those needs.
Abdominal evaluation of the distension, rigidity, sensitivity and presence of masses obtained through the physical examination and articulation between the reference and counter-referral system recommended by the Unified Health System (UHS) were identified as gaps.

\section{CONCLUSION}

This research allowed the analysis of national and international studies on nursing care for people with gastrostomy. There was a shortage of articles on this subject and this is an important issue for nurses, since the number of patients submitted to this procedure is increasing.

The studies revealed a greater concern with procedural technical care and relational skills. In this sense, it should be emphasized that nurses should better explore their clinical role and that systematized nursing care should be better discussed and studied, especially in UHS.

This study contributes to the advancement of nursing practice by reiterating that nurses should better explore their clinical practice in both hospital and home care.

It is suggested that further studies be developed in this area to raise awareness and increase the knowledge of nursing professionals and the health team to understand the experience of the person with gastrostomy.

\section{AUTHOR'S CONTRIBUTION}

Conceptualization, Silva TP; Ribeiro CRG; Resck ZMR; Fava SMCL and Dázio EMR; Methodology, Silva TP and Ribeiro CRG; Investigation, Silva TP; Ribeiro CRG; Resck ZMR; Fava SMCL and Dázio EMR; Writing - First edition, Silva TP; Ribeiro CRG; Resck ZMR; Fava SMCL and Dázio EMR; Writing - Revision \& Edition, Resck ZMR; Fava SMCL and Dázio EMR.

\section{REFERENCES}

1. Bertevello PL, Sobreira RS, Morais PAB. Gastrostomia: indicações, técnicas e cuidados no adulto. In: Santos VLCG,
Cesaretti IUR. Assistência em estomaterapia: cuidando de pessoas com estomia. São Paulo: Atheneu; 2015. p. 131-51. 
2. Santos JS, Kemp R, Sankarankutty AK, Salgado Junior W, Tirapelli LF, Silva Junior OC. Gastrostomia e jejunostomia: aspectos da evolução técnica e da ampliação das indicações. Med (Ribeirão Preto Online). 2011;44(1)39-50. doi: 10.11606/issn.2176-7262.v44i1p39-50.

3. Nascimento NG, Borges EL, Donoso MTV. Assistência de enfermagem a pacientes gastrostomizados baseado em evidências. Rev Enferm Cent O Min. 2015 set/dez;5(3):1885-97.

4. Mendes KDS, Silveira RCP, Galvão CM. Revisão integrativa: método de pesquisa para a incorporação de evidências na saúde e na enfermagem. Texto Contexto Enferm. 2008;17(4)758-64. doi: 10.1590/s010407072008000400018.

5. Melnyk BM, Fineout-Overholt E. Evidence-based practice in nursing \& healthcare. A guide to best practice. 2nd ed. Philadelphia: The Point; 2011.

6. Friginal-Ruiz AB, González-Castillo S, Lucendo AJ. Gastrostomía endoscópica percutánea: una actualización sobre indicaciones, técnica y cuidados de enfermería. Enfermería Clín. 2010;21(3)173-8.

7. Lucendo AJ, Friginal-Ruiz AB. Percutaneous endoscopic gastrostomy: an update on its indications, management, complications, and care. Rev Esp Enferm Dig. 2014;106(8)529-39.

8. Simons S, Remington R. The percutaneous endoscopic gastrostomy tube: a nurse's guide to PEG tubes. Medsurg Nursing. 2013;22(2)77-83. Acesso em: 20/11/2015.
9. Brotherton AM, Abbott J, Hurley M A, Aggett PJ. Home percutaneous endoscopic gastrostomy feeding: perceptions of patients, carers, nurses and dietitians. J Adv Nurs Preston. 2007;59(4)388-97. doi: 10.1111/j.13652648.2007.04307.x.

10. Nascimento NG, Borges EL, Donoso MTV. Assistência de enfermagem a pacientes gastrostomizados baseada em evidências. R Enferm Cent O Min. 2015;5(3)1885-97.

11. Silva NG, Gama FA, Dutra RA. Percepção de pacientes com estomia sobre mitos e medos relacionados a esta condição. Rev Estima. 2008;6(1).

12. Forest-Lalande L. Gastrostomia para nutrição enteral. Campinas: Lince; 2011.

13. Souza JL, Gomes GC, Barros EJLB O cuidado à pessoa portadora de estomia: o papel do familiar cuidador. Rev Enferm UERJ. 2009;17(4)550-5.

14. Vilarinho RSC, Rogenski NMB, Rogenski KE. Como cuidar de pessoas com gastrostomia. In: Paula MAB, Paula PR, Cesaretti IUR. Estomaterapia em foco e o cuidado especializado. 1a ed. São Caetano do Sul: Yends; 2014.

15. Cruz AC, Angelo M, Gamboa SG. A visão da família sobre a experiência de ter uma criança gastrostomizada. Rev Enf Ref 2012;3(8)147-53. doi: 10.12707/riii1216

16. Malhi H, Thompson R. PEG tubes: dealing with complications. Nurs Times. 2015;110(45):18-21. 